\title{
DETERMINISME TEKNOLOGI DAN POSISI MEDIA DECENTER PADA KASUS PEMBERITAAN KECELAKAAN MAUT DI TUGU TANI JAKARTA
}

\author{
Mubarok, S.Sos, Msi \\ (mubgabus@gmail.com) \\ (Dosen FIKOM, Universitas Islam Sultan Agung Semarang)
}

Abstract

Deadly accident at Tugu Tani Jakarta not only shows the human side of an event. Dissemination of information through mass media is no longer dominant in determining how the audience should act. The emergence of social networking sites opens new channels for the dissemination of public information that is more believable. The development of information technology not only marked by the turn of the communication device but coupled with changes in the behavior of human users. They are actively selecting and using various media to meet the information needs, socialize, trade, and show the existence. The position of the mass media is no longer dominant in determining the type of information and the consuming public dictates the type of information. Through a social networking site and diverse site audience and information providers are actively selecting and using various types of information. In this position the media as marginalized (decenter) and does not become a major reference source.

Kata Kunci : Determinisme Teknologi, Media, Decenter, Informasi

\section{PENDAHULUAN}

Kecelakaan maut yang
menewaskan sembilan orang
terjadi pada hari Minggu 22
Januari 2012 . Kecelakaan

berlangsung, minggu siang, ketika rombongan orang yang baru kelar berolah raga di Monas, tiba-tiba ditabrak mobil yang dikendarai Apriyani Susanti. Saksi mata menuturkan, mobil yang dikendaraai perempuan bertubuh besar itu melaju kencang dari arah Monas ${ }^{1}$.

Sopir Daihatsu Xenia hitam bernomor polisi B 2479 XI yang menabrak delapan pejalan kaki di Jalan Ridwan Rais, Jakarta Pusat, berinisial AS, wanita berusia 29 tahun. Saat diperiksa, AS tak bisa memperlihatkan Surat Izin Mengemudi dan hanya memperlihatkan STNK atas nama orang lain. Polisi masih mendalami penyebab kecelakaan. Saksi mata di lokasi, Suwarto (40), menduga sopir mabuk saat mengendarai kendaraan. Namun Kasat Lantas Polres Jakpus Komisaris Gimo Husodo memperkirakan penyebab kecelakaan adalah rem mobil yang tak berfungsi dengan baik ${ }^{2}$.

Berita kecelakaan maut yang terjadi di Jakarta tersebut segera menyedot perhatian jutaan orang di seluruh Indonesia. Beragam komentar, analisa, ide, 
masukan, cacian dan luapan emosi lainnya memenuhi ruang maya di berbagai

kanal. Lokasi kecelakaan yang terjadi di Jakarta membuat magnitude peristiwanya semakin besar. Lokasi ibu kota negara memudahkan penyebaran informasi. Dunia yang terbentang dalam jutaan kilometer jarak di darat dan laut bukanlah penghalang untuk mengetahui peristiwa terkini yang terjadi di berbagai tempat. Perkembangan teknologi di bidang komunikasi membuat penyebaran informasi semakin cepat, mudah dan menjangkau berbagai belahan dunia. Kondisi tersebut menjadi menarik untuk melihat bagaimana kekuatan determinisme teknologi dan posisi media massa yang selama ini dianggap sebagai sumber informasi yang paling banyak diakses. Tulisan ini bermaksud untuk mengkaji teori determinisme teknologi dan posisi media decenter pada kasus pemberitaan kecelakaan maut di Tugu Tani Jakarta.

\section{PEMBAHASAN}

Perkembangan teknologi
komunikasi memungkinkan
penyebaran informasi yang cepat
dan bersifat massif. Internet
membuka ruang dengan
menawarkan akses tak terbatas dan
kecepatan diseminasi informasi.
Dalam contoh kasus kecelakaan
maut di Tugu Tani tersebut
nampak nyata bagaimana
determinisme r teknologi
komunikasi membuat setiap orang
memiliki kesempatan untuk

mendapatkan akses tercepat terhadap informasi. Seandainya teknologi informasi belum seperti sekarang tentunya penyebaran informasinya tidak akan secepat itu. Media cetak paling cepat bisa menghadirkan informasi tersebut sore hari.

Marshall McLuhan adalah pencetus dari teori determinisme teknologi pada tahun 1962 melalui tulisannya The Guttenberg Galaxy : The Making of Typographic Man. Dasar teorinya adalah perubahan pada cara berkomunikasi akan membentuk cara berpikir, berperilaku, dan bergerak ke abad teknologi selanjutnya di dalam kehidupan manusia. Sebagai intinya adalah determinisme teori, yaitu penemuan atau perkembangan teknologi komunikasi merupakan faktor yang mengubah kebudayaan manusia. Di mana menurut McLuhan, eksistensi manusia ditentukan oleh perubahan mode komunikasi. McLuhan berpikir bahwa budaya kita dibentuk oleh bagaimana cara kita berkomunikasi. Paling tidak, ada beberapa tahapan yang layak disimak. Pertama, penemuan dalam teknologi komunikasi menyebabkan perubahan budaya. Kedua, perubahan di dalam jenisjenis komunikasi akhirnya membentuk kehidupan manusia. Ketiga, sebagaimana yang dikatakan McLuhan bahwa "Kita membentuk peralatan untuk berkomunikasi, dan akhirnya peralatan untuk berkomunikasi yang kita gunakan itu akhirnya membentuk atau mempengaruhi kehidupan kita sendiri”.

Dalam kasus tabrakan maut di Tugu Tani, persebaran informasi 
yang begitu cepat tidak lepas dari dua hal penting, pertama, ada teknologi komunikasi yang dipakai media massa untuk menyampaikan pesan secara massif dan cepat. Internet sebagai new media juga berperan penting dalam persebaran informasi tersebut di dunia maya. Kedua, ada perubahan budaya dalam masyarakat informasi yang dipengaruhi perkembangan teknologi. Eksistensi masyarakat komunikasi sangat dipengaruhi oleh perkembangan teknologi tersebut. Masyarakat saat ini tidak hanya menggantungkan diri pada informasi yang diperoleh melalui media massa (cetak dan elektronik) melainkan juga aktif mencari sumber lain seperti situs jejaring sosial dan media online lainnya.

Selain penyebaran informasi dari portal berita resmi, peristiwa kecelakaan maut di Tugu Tani juga menyebar melalui situs jejaring sosial yang banyak digunakan oleh masyarakat. Berikut contoh berita di twitter tentang kecelakaan maut tersebut.

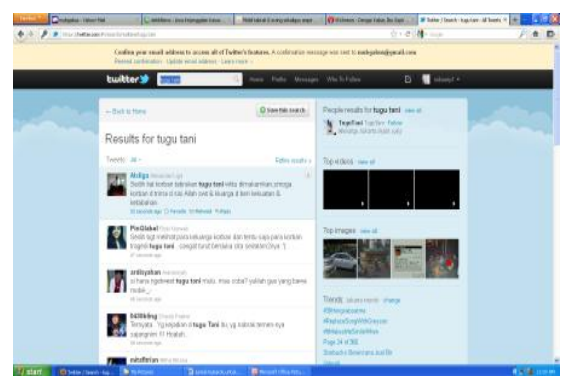

Twitter $^{3}$ saat ini menjadi salah satu situs jejaring sosial yang digemari masyarakat. Informasi yang disajikan melalui situs ini juga memiliki jangkauan yang luas. Konsep citizen journalism yang mungkin berkembang dengan memanfaatkan situs ini didukung oleh jutaan pengguna yang tersebar di berbagai pelosok dunia. Mereka secara aktif memberikan informasi terkini tentang beragam kejadian yang terjadi di sekitarnya. Kecepatan informasi yang disajikan terkadang melebihi portal berita resmi yang dikelola lembaga penerbitan pers.

Selain twitter situs lain yang juga banyak dipercaya untuk penyebaran informasi adalah Kaskus. Berikut Contoh sumber dari kaskus:

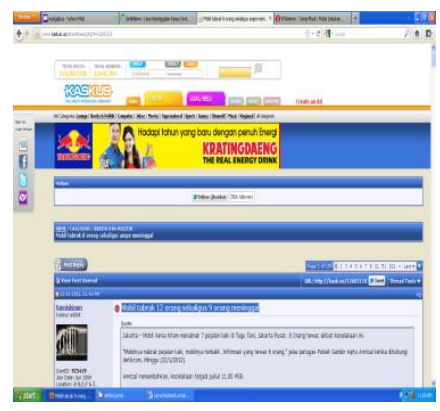

Berita di portal Kaskus tersebut merupakan bagian dari diseminasi informasi yang diambil dari portal lain kemudian diberikan komentar beragam oleh para anggotanya. Kaskus menjadi salah satu portal yang memiliki banyak anggota dan mendiskusikan beragam kasus yang sedang terjadi. Kaskus juga menjadi rujukan untuk berdiskusi beragam produk, situasi politik dan berbagai aktifitas sehari-hari yang dialami anggotanya. Kelebihan dari situs jejaring sosial, portal yang dikelola dan beranggota massif terletak dari tingginya tingkat posting informasi dan berimbas pada naiknya tingkat kepercayaan. Sebagai contoh para anggota Kaskus ketika menerima informasi atau ingin membeli barang terlebih dahulu akan meminta pendapat dari anggota 
lainnya. Kaskus menjadi tempat untuk berdiskusi dan berbagi informasi sebelum memutuskan sesuatu. Pada kasus kecelakaan maut di Tugu Tani para anggota Kaskus berdiskusi secara aktif dan menambahkan informasi sesuai dengan kedekatan

para anggotanya dengan lokasi kejadian. Mereka juga bisa memberikan deskripsi kejadian, pelaku, korban dan suasana di lokasi kejadian. Hal tersebut sangat dimungkinkan karena anggota Kaskus jumlahnya ribuan dan tersebar di berbagai tempat.

Twitter dan Kaskus menjadi contoh bagaimana sebuah situs jejaring sosial dan portal yang beranggotakan jutaan orang menjadi sumber rujukan untuk memperoleh informasi. Kondisi ini memunculkan sebuah pertanyaan, apakah posisi media massa telah terpinggirkan? Untuk mengkaji fenomena tersebut berikut akan diuraikan pendekatan ekonomi politik dan posisi media decenter.

Pendekatan ekonomi politik memfokuskan pada kajian utama tentang hubungan antara struktur ekonomi dan politik, dinamika industri media, dan ideologi media. Perhatian penelitian ekonomi politik diarahkan pada kepemilikan, kontrol serta kekuatan operasional pasar media. Dari titik pandang ini, institusi media massa dianggap sebagai sistem ekonomi yang berhubungan erat dengan sistem politik. Ekonomi politik komunikasi menyebutkan bahwa media massa, bukan lagi satusatunya sumber informasi yang dapat berdiri sendiri, melainkan informasi yang dibentuk berasal dari berbagai macam hal yang berada di sekitarnya. Hal ini dipahami sebagai konsep decentering the media di dalam ekonomi politik komunikasi. Bentuk seperti itu yang kemudian memberikan dua muka kepada media massa, sebagai sebuah lembaga yang wajib memberikan informasi kepada masyarakat luas, namun juga sebagai alat "propaganda" bagi kuasa.

Oleh karena itu pendekatan ini menghindari kecenderungan ontologis esensialisme komunikasi yang menganggap komunikasi sebagai satu-satunya realitas sosial yang paling penting. Teori ekonomi politik komunikasi meminggirkan posisi media (decenter the media) dan melihat sistem komunikasi sebagai bagian integral dari proses ekonomi, politik, sosial dan budaya masyarakat. Media ditempatkan dalam kerangka produksi dan reproduksi yang dibentuk berdasar unsur-unsur akumulasi modal, tenaga kerja, dan lainnya . Media sama dengan dimensi ekonomi, politik, sosial, budaya, pendidikan, keluarga, agama dan aktivitas kelembagaan. Semua aktivitas kelembagaan tersebut dibentuk dalam kapitalisme.

Dalam kasus diseminasi informasi kecelakaan Tugu Tani posisi media massa bukan lagi satu-satunya sumber yang dipercaya oleh masyarakat. Situs jejaring sosial dan portal lain seperti Kaskus menjadi rujukan yang dipercaya. Pengembangan dari kebiasaan getok tular (penyebaran informasi dari individu ke individu lain secara langsung) yang ada di masyarakat Indonesia memposisikan media 
massa hanya sebagai bagian dari sistem diseminasi informasi.

Media massa dengan beragam kepentingan ekonomi dan politik yang melingkupinya dipandang cerdas oleh audience sebagai bagian integral dari sistem diseminasi informasi. Masyarakat secara cerdas memilih sumber informasi yang bisa dipercaya. Kegiatan komuikasi dalam segala bentuk dan salurannya bukanlah satu-satunya kepentingan manusia, komunikasi menjadi bagian integral dari sistem sosial dan budaya yang lebih besar. Sisi kepentingan bisnis yang diusung media mengarahkannya untuk mencari keuntungan sebesarbesarnya, sementara bagian dari tanggungjawab sosialnya mewajibkan untuk menyajikan informasi yang bermanfaat bagi manusia.

Dalam posisi tersebut auidence memandang secara cerdas posisi media sehingga bisa mengurangi ketergantungan terhadap sumber informasi profit. Media situs jejaring sosial dan portal beranggota masif yang hidup dari keaktifan anggotanya menjadi pilihan lain sebagai sumber informasi.

\section{a. Penutup}

Perkembangan teknologi informasi tidak hanya ditandai dengan pergantian piranti komunikasi tetapi dibarengi dengan perubahan perilaku dari manusia penggunanya. Mereka secara aktif memilih dan menggunakan beragam media untuk memenuhi kebutuhan informasi, bersosialisasi, bertransaksi, dan menunjukkan eksistensi. Posisi media massa tidak lagi dominan dalam menentukan jenis informasi dan mendikte khalayak dalam mengkonsumsi jenis informasi. Melalui situs jejaring sosial dan beragam situs penyedia informasi lainnya khalayak secara aktif memilih dan menggunakan beragam jenis informasi. Pada posisi ini media seolah terpinggirkan (decenter) dan tidak menjadi sumber rujukan utama.

Dalam kasus diseminasi informasi kecelakaan maut Tugu Tani nampak bahwa penyebaran informasi menjadi lebih massif ketika khalayak juga memanfaatkan twitter dan Kaskus sebagai sumber rujukan informasi. Melalui twitter mereka berbagi informasi dan memberikan pendapat, ide, bahkan cacian. Pada khalayak aktif, determinisme teknologi tidak hanya ditentukan oleh perubahan jenis teknologi, cara penyebaran informasi tetapi juga ditentukan oleh budaya dari khalayak penggunanya.

\section{Daftar Pustaka}

Croteau, David and Hoyness, William, 2000, Media Society, Second edition, California:Sage Publications.

Curran, James, Gurevitch, Michael, 1991, Mass Media and Society, Routledge Chapman Hall inc:New York

Littlejohn, S. W. 2008. Theories of Human Communication $9^{\text {th }}$ Edition", Belmont CA:Wadsworth N/A

Mosco,Vincent, The Political Economy Of Communication, SAGE Publications, London, 1996.

Nurudin, 2007, Pengantar Komunikasi

Massa, Jakarta, Rajawali Pers 
Sunarto, 2009, Televisi, kekerasan dan Perempuan, Jakarta: Kompas

Metrotvnews.com,pada 24/1/2012/09.50

Berita.liputan6.com pada 24/1/2012/10.00 http://id.wikipedia.org/wiki/Twitter,30/1/2 012/09.30

wikipediahttp://id.wikipedia.org/wiki/Kas kus, diakses, 27/1/2012, 09.37) 